\title{
A LEGAL AND ADMINISTRATIVE ANALYSIS OF INALIENABLE MUSLIM ENDOWMENTS (AWQĀF) IN BOSNIA AND HERZEGOVINA
}

\author{
Adnan Trakic*
}

\begin{abstract}
The establishment of inalienable Muslim endowments (pl. awqāf; sing. waqf) in Bosnia and Herzegovina goes back to the days of the Ottoman occupation of the region in 1463. This article explains their establishment and development together with their institutions with reference to the fifteenth and sixteenth centuries when some of the most famous awqāf emerged. The great period for awqāf came to an end with the Austria-Hungarian takeover in 1878. The author argues that since then the institution of waqf in Bosnia and Herzegovina was subject to injustice, hostility, and devastation from the various regimes that have ruled the country. He explains the deteriorating position of waqf property through the periods of the Kingdom of Yugoslavia and the unlawful confiscation and nationalisation of waqf property and the ultimate complete abolition of the institution of waqf under the communist and socialist regime. This situation lasted until the independence of Bosnia and Herzegovina in 1992 when the Council of the Islamic Community of Bosnia and Herzegovina established the Waqf Directorate. The author also evaluates the legal applications of the restitution claims made by religious communities for the property which was unlawfully confiscated through various legislative mechanisms during and after the communist regime. The ways to safeguard and protect waqf property will be examined as well.
\end{abstract}

\section{The Origin of Waqf and Its Socioeconomic Importance}

The institution of waqf is a unique establishment in Islam which promotes the social, ethical, and moral values of human beings. These values must not be overtaken by greed, selfishness, and ignorance. The best reminder of the quality of human beings is the existence of $a w q \bar{a} f$ (pl. of $w a q f$ ) in most of the Muslim communities as a seal of understanding, tolerance, and willingness to help. The debate in the west is ongoing

* Adnan Trakic is a PhD Candidate at the Ahmad Ibrahim Kulliyyah of Law, International Islamic University Malaysia (IIUM) and a Lecturer at the School of Business, Sunway University, Kuala Lumpur, Malaysia. This article is an extended version of a paper presented by him at the 'International Conference on Waqf Law and Management', held on 20-22 October 2009 in Kuala Lumpur, organised by the IIUM Endowment Fund, and sponsored by Sime Darby, a Malaysia-based diversified multinational. 
on the responsibilities of man towards the upcoming generations, and that reminder has got to be emphasised all the time. On the other hand, the institution of waqf in Islam clearly shows the complete concern of the wäqif (the person establishing a waqf) towards the next generations by leaving them the property to be used wisely for their benefit. This brings about the social aspect of the waqf. When it comes to the economic aspect of the waqf, the economic system in which the general directions of the Qur'ān are incorporated can be considered as a specific system of economic thought in Islam. Islam strongly supports the idea of mutual help, coordinated and collective efforts, and efficient management for the common good.

The word waqf comes from the Arabic verb waqafa, which etymologically means 'to hold', 'to keep', or 'to detain'. The legal meaning of waqf, according to the early Muslim jurist, Imām Abū Hanīfah (d. 767), is the detention of a specific thing in the ownership of a wāqif or appropriator and the devoting or appropriating of its profits or usufruct "in charity to the poor or other good objects." According to his two disciples, Abū Yūsuf (d. 798) and Muḥammad al-Shaybānī (d. 805), waqf signifies the extinction of the appropriator's ownership in the thing dedicated and the detention of the thing in the implied ownership of Allah in such a manner that its profits may revert to or be applied "for the benefit of mankind." A waqf extinguishes the right of the wäqif or dedicator and transfers ownership to Allah. A mutawalli is the manager of the waqf, but the property does not vest in him. A waqf may be made in writing or its dedication may be oral. There must, however, be appropriate words to show an intention to dedicate the property. The use of the word waqf is neither necessary nor conclusive. ${ }^{2}$

The difference between the institution of waqf and a 'trust' under English law has to be admitted here. This has been explained in the case of Vidyavaruthi v. Baluami by the Privy Council in which they clarified that 'Mahomedan Law' relating to trust differs fundamentally from English law. Furthermore the lords of the court explained that the 'Mahomedan' concept of trust owes its origins to a rule laid down the Prophet of Islam and means 'the drying up of property in the ownership of God the Almighty and the devotion of the profits for the benefit of human beings'. Once it is declared that a particular property is waqf or any such expression is used as implying waqf or the tenor of the document shows that a dedication to a pious or charitable purpose is meant, the right of the wāqif is extinguished and the ownership is transferred to the Almighty. The donor may name any meritorious object as the recipient of the benefit. ${ }^{3}$

Generally, Islam permits the transfer of property under an individual's possession to another person through the instrument of sale, gift or inheritance. At the same time, the utilisation of the property by an individual for his own benefit is also accepted in principle. However, a person can impose restrictions on the transfer of property, both movable and immovable, by declaring it as a waqf. Therefore, one can transfer the profits accruing from such property from the sphere of a limited individual's benefit of a much larger number of people comprising the weaker sections of not only the 
Muslim ummah, but the entire humanity. The ownership of the property so declared as waqf vests in Allah. ${ }^{4}$

Waqf is established based on the Qur'ān and Sunnah. Almost all verses of the Qur'ān which prescribe legal rulings were revealed in Medina. One of those qur'ānic verses referring to the authority for the establishment of waqf is 3:92 where it is stated: "You will never attain virtue until you spend something you are fond of; while God is aware of anything you may spend." In interpreting this verse, the Prophet (according to al-Bukhārī and Muslim) says: "After the death of man, his traces in this world will disappear except in three situations: if he leaves perpetual good (sadaqah), the knowledge that will benefit others, and a well brought up child that will pray for him." The word waqf is linked to the name of the Prophet Ibrāhīm (Abraham). In Palestine, even until today, there is a town known by the Muslims as al-Khalīl (Hebron) which, they believe, was built from the property of Ibrāhīm as waqf, and one of Ibrāhīm's biggest waqfs is the Ka'bah in Mecca which he built, according to Muslims, upon the direct instruction of Allah.

Furthermore, it has been reported that the second caliph, 'Umar b. al-Khațāa (r. 634-44) once came to the Prophet Muhammad and said that the property that he owns in Khaybar is the one that he likes the most, that it is the one that is the most useful to him, and that he wishes to make it as a perpetual good (sadaqah).The Prophet replied to him that the best deed would be if he detains it from his property (waqf) with a declaration that that property should neither be sold, inherited or gifted in the future. When 'Umar heard the Prophet, he made a declaration that the benefits and usufruct from his property should be given for the needs of the poor, his family, soldiers, travellers, and the freeing of slaves, and there shall not be sin if the manager (mutawallī) uses the benefits for his own food in a moderate way and as well as to feed his friends. The example of 'Umar was followed by other Companions of the Prophet as well, and for that matter there are some historians who claim that all Companions of the Prophet have left at least some of their property as waqf. The Prophet himself left seven of his gardens as waqf.

At that particular time, everything that could be useful to the Muslim community for its social and economic development was left over to the ummah to be used as both movable and immovable property. Subsequently, the Islamic state was spreading and Muslims from different social and cultural background became its subjects. That is the time that new issues appeared before the Muslim legal scholars who had to come out with new rulings suitable for a particular time and place. This is also the time when differences of opinion and manifold rulings in relation to waqf emerged, such as whether movable property can constitute waqf or whether a wäqif can use the waqf property for his own benefit as long as he is alive, etc. Nevertheless, the waqf is still a very developed tradition among the Muslims in Bosnia and throughout the world, and its socioeconomic implications and benefits can be seen in Muslim society. ${ }^{5}$ 
The origin and the importance of waqf were discussed by various scholars such as Henry Cattan. He observed that the institution of waqf developed with Islam, and there is no evidence that such a complex system of appropriating usufruct as a life-interest to varying and successive classes of beneficiaries existed prior to Islam. Although the separation of ownership from the usufruct was not a new legal concept, the settlement of usufruct or property on successive generations in perpetuity for an immediate or ultimate charitable purpose is an instruction developed by the Muslim jurists during the first three centuries of Islam. Furthermore, the late Henry Cattan (d. 1992) stated that the similarity and resemblance between the Islamic concept of waqf and the English concept of 'trust' poses the question whether the English concept was derived from the Islamic one. When it comes to time, there is no doubt that waqf, as it exists in its present form, was developed and established during the eighth and ninth centuries, while English 'trusts' or 'uses' were developed in the thirteenth century. Also according to Cattan, this clearly shows that it would be reasonable to suggest that the English concept of 'trust' actually originates from the Islamic concept of waqf. ${ }^{6}$

\section{The Establishment of Waqf in Bosnia and Herzegovina}

\section{During the Ottoman Period}

The establishment of waqf in Bosnia and Herzegovina is closely connected with the occupation of that region by the Ottoman Empire. Therefore, before embarking on the discussion of waqf during that period, a few words about the Ottoman occupation of Bosnia would be appropriate. In 1463 Maḥmūd Pasha, under the direction of Sultan Muhammad II the Conqueror (r. 1444-46 and 1451-81), led the Ottoman armies to victory over hostile forces in Bosnia. By 1492, the year when the Muslims lost their control over Spain, the rest of Herzegovina came under Ottoman rule as well. The Bogomils ${ }^{7}$ are said to have declared en masse their allegiance to the Ottoman Empire and their acceptance and submission to the Islamic faith. Safet Abid, an American Muslim of Bosnia-Herzegovinian and British extraction, stipulates in his article entitled "Islam in Bosnia and Herzegovina" that the Ottomans - contrary to other currently prevailing views - did not enforce the conversion to Islam 'by the sword'. Instead, he argues, the Ottomans guaranteed religious freedom and simply ensured the administrative functioning of the conquered land - although it should be noted here that there are, of course, also views to the contrary. In Abid's view, such a 'mass acceptance' of Islam by various indigenous populations was not unusual in Muslim history. ${ }^{8}$

From the mid-fifteenth and throughout the late seventeenth centuries, Bosnia and Herzegovina blossomed as centres of Muslim culture, education, and commerce in the western parts of the Ottoman Empire. ${ }^{9}$ In 1537, under the direction of the regional Ottoman governor, Gazi Hüsrev Beg (d. 1541), an effective Bosniak military 
strategist and the greatest donor and builder of Sarajevo, the first major madrasah was established in Sarajevo. The aim of this new madrasah was the complete integration of the latest sciences of the time, such as mathematics, literature, and natural sciences, plus the traditional religious sciences such as Islamic theology, tafsīr (qur'ānic exegesis), hadìth (prophetic traditions), and ușūl al-fiqh (principles of Islamic jurisprudence). ${ }^{10}$

During the Ottoman period, most of the administrative, constitutional, and legal matters were handled by the administrative branch which was supported by the military. Other affairs, such as culture, education, and social matters were represented and handled by the institution of waqf. The importance of waqf in the early stages of the Ottoman period was tremendous. It was unimaginable at that time for any of the towns to be built without the supervision and help of the waqf institution. Therefore, most of the structural centres of the towns represented by various objects of educational, cultural, or religious life of the Muslims were based on waqf. ${ }^{11}$

Thus flourishing of waqf in Bosnia and Herzegovina was during Ottoman rule, and toward the end of Ottoman rule, there were more than 5,000 awqa $f$ in Bosnia. These $a w q \bar{a} f$ were administered by mutawalliss (managers) appointed according to the will of benefactors as expressed in the establishment deeds known in Ottoman-Turkish as waqfnames. It is interesting to note that the Ottoman waqf ministry exercised a rather loose supervision over the administration of Muslim endowments in the province as there was no centralised documentation on waqf property and their income and expenditure. ${ }^{12}$

\section{Under the Habsburg Monarchy}

When Ottoman Bosnia fell to the Austro-Hungarian Habsburg Empire in 1878, the control over $a w q \bar{a} f$ was taken over by the newly established (non-Muslim) provincial government. Subsequently, after ten years of its waqf administration in Bosnia, the provincial government issued an ordinance which introduced a uniform and stable administration of waqf affairs. Two bodies were established, namely: ${ }^{13}$

- the Provincial Waqf Commission (PWQ), and

- the Provincial Waqf Board (PWB).

The duty of the Provincial Waqf Commission (PWQ) was to ascertain details of all $a w q \bar{a} f$ in the land, to control their expenditure, and to carry out new regulations regarding the waqf administration. The following year, the PWQ was established in all districts. The establishment of those commissions in every district across the country shows the amount of waqf land available in almost in every district of Bosnia at that time. These commissions were entrusted with the duty to provide detailed surveys of existing Muslim endowments in Bosnia to the Provincial government 
and to supervise the local mutawallis. ${ }^{14}$ The PWQ was composed of the President, Inspector, Secretary, four members of the council of Muslim clerics (majlis al'ulama'), two High Sharī'ah Court judges, and two prominent Muslims from each of Bosnia's six districts.

The Provincial Waqf Board (PWB), on the other hand, was an executive body whose main duty was to assist the PWQ with the fieldwork and gathering of any information in relation to waqf administration in every district. The PWB was composed of the President, Inspector and Secretary of the PWQ, with necessary clerical staff. In the districts these waqf boards were headed by shari ${ }^{-} a h$ judges. Unfortunately, the members of those bodies were appointed by the Habsburg administration, a circumstance which left considerable space for the misuse of $a w q \bar{a} f$ for purposes other than those which are permitted by Islamic law.

Initially, the formation of those bodies governing the waqf administration looked as if it would bring about positive effects on the preservation and righteous use of $a w q \bar{a} f$ among the Bosnian Muslim community. However, in many instances the misuse of $a w q \bar{a} f$ by the non-Muslim government, due to the appointed members of those two governing bodies, became obvious. The dominant rule of bureaucrats led toward an administration which emphasised the financial aspect of waqf over its religious, educational and charitable purposes. Those appointed waqf officials drew high salaries at the cost of the ultimate beneficiaries of endowments: schools, mosques, and the poor and the like. The misuse of $a w q \bar{a} f$ led Bosniaks to believe that the waqf funds were used by the non-Muslim government for their own administrative purposes. ${ }^{15}$

The Muslims in Bosnia became increasingly unsatisfied, until an incident in Herzegovina caused the Bosniaks to take things into their own hands: In 1899, an underaged Muslim girl from the town of Mostar - Fata Omanovic - was taken away by Catholic nuns, converted to Christianity, and secretly sent to Austria to marry an Austrian officer. This event caused outrage among the local Muslim community. Demonstrations were led by Ali Fehmi Dzabic (1853-1918), ${ }^{16}$ the mufti of Mostar, who submitted demands to the Habsburg administration demanding the reorganisation of Muslim religious affairs, in particular the waqf and educational sectors. ${ }^{17}$ A mass movement for religious autonomy was born. The movement demanded the reshaping of the waqf administration in such a way that members of waqf bodies would be elected by the Muslims themselves. Dzabic was the leader of this movement until his visit to Ottoman Istanbul, when the Habsburg administration prohibited him from returning back to Bosnia and Herzegovina.

As a result of the constant pressure by Bosniaks, Vienna accepted most of the movements' demands pertaining to the administration of Islamic affairs. The Statute for Autonomous Administration of Islamic Religious, Waqf, and Educational Affairs in Bosnia and Herzegovina was adopted on 15 April 1909. By virtue of this statute, the autonomy and election of an authority administering the waqf were granted. The 
jurisdiction of sharī ah courts was confirmed in cases of litigation over waqf property where the waqf capacity of that property was not disputable. ${ }^{18}$

\section{Under the Kingdom of Yugoslavia}

In 1918, following the defeat of the Central Powers in World War I, the 'Kingdom of Serbs, Croats, and Slovenes' was created, as a result of which the identity and the freedom of Muslims were weakened. In 1929, the kingdom was renamed 'Yugoslavia'. ${ }^{19}$ During the 'Kingdom of Yugoslavia' period there was a dispute over the authority regarding waqf property between the government and the local Muslim community, ${ }^{20}$ the latter claiming an autonomous administration. In 1930, King Alexander I Karađorđević (r. 1918-34) abolished the statute for the Autonomous Administration of Islamic Religious, Waqf, and Educational Affairs. ${ }^{21}$ Subsequently, in 1936 the Law on the Islamic Community was introduced. Compared to the previous statute, this law had offered some more up-to-date solutions in preserving waqf property. However, the political and administrative aspects of government influence were easily noticeable in the sections of this statute which undermined its quality and independence. ${ }^{22}$

\section{Under the Socialist Federal Republic of Yugoslavia: The Nationalisation of Waqf in Bosnia and Herzegovina}

The Socialist Federal Republic of Yugoslavia was a state that existed from the second half of World War II (1943) until it was formally dissolved in 1992. It was led by Josip Broz Tito (1892-1980). During that period, Bosnia and Herzegovina became the 'Socialist Republic of Bosnia and Herzegovina' which was under the control of the Federal Government of the Socialist Federal Republic of Yugoslavia in Belgrade. During the 'Socialist Republic of Bosnia and Herzegovina' period, the status of waqf became highly unpredictable. In fact, it can be said with confidence that this was one of the most difficult times for waqf in Bosnia and Herzegovina. It was also the time of communist rule, whereby the postulate that 'religion and politics' must be separated was predominant. ${ }^{23}$

The process of the nationalisation of waqf property starts with the coming into force of the Laws on Reform of Agriculture and Colonisation of Bosnia and Herzegovina ${ }^{24}$ together with other laws and regulations whereby the state took by force nearly everything of the waqf property with the exception of mosques and their minarets - in accordance with its atheistic point of view - leaving Muslims in Bosnia to face grave injustice whose consequences can be felt even until today. Section 3(c) of the Laws on Reform of Agriculture and Colonialisation [sic] of Bosnia and Herzegovina explains that land which was owned and possessed by mosques, churches, and religious and educational institutions shall become the possession of 
the state. Furthermore, Section 4 states that the ownership of the state is absolute over confiscated types of land whereby the fixtures and cattle, including buildings and agricultural cultivations, would become the sole property of the state without compensation. Finally, the amount of land that is allowed to be owned and possessed by the religious institutions is provided for in Section 8(1), (2), whereby it says that the amount of ownership of land given to the religious institutions should not exceed 10 hectares while the religious institutions with 'greater importance' to society can own up to 30 hectares of land and forest. Two years after the introduction of the agricultural reform laws, on 26 August 1947, the local Muslim community came out with a Constitution of the Islamic Community of the Socialist Federal Republic of Yugoslavia which also established structural organs of its organisation. However, according to Senad Ceman, the new structural organisation of waqf, as well as religious and educational affairs, did not change dramatically from the previous one. ${ }^{25}$

The extraordinarily harsh attitude of communist regime towards the waqf at this particular time culminated in the year 1958 when the Laws on Nationalisation of Leased Buildings and Land was legislated. The purpose of this piece of legislation was to take the last breath of the Islamic Community. By this piece of legislation, the Islamic Community was left overnight without any immovable property - except the mosques. ${ }^{26}$ The waqf land, the forests, and the buildings - the financial skeleton of the Islamic Community for its maintenance and very existence - were simply taken away. ${ }^{27}$ Subsequently, on 13 July 1959, there was an emergency meeting of the Islamic Community in which a new constitution had been adopted which abolished the existence of the organs and administration of waqf because the new legislation on the nationalisation of waqf had caused it to slip out of its control. As a purely religious organisation, the Islamic Community remained secluded from any active participation in the lives of Muslims in Bosnia and Herzegovina. The mosques were maintained from the alms and financial contributions of Muslim families on a purely individual basis. From among the relevant statutes and regulations legislated in favour of the nationalisation of waqf throughout the communist period the following deserve special mention: ${ }^{28}$

- Laws on the Confiscation of Property and the Methods of Confiscation (Official Gazette of Democratic Federal Yugoslavia) No. 40/45 and 70/45;

- Laws on the Handling of Confiscated Property which Was Confiscated from the Owners by Authorities and their Assistants and Property that Owners had Left (Official Gazette of Democratic Federal Yugoslavia) No. 36/45; and

- Laws on the Nationalisation of Private Limited Companies (Official Gazette of Democratic Federal Yugoslavia) No. 98/46, 99/46, 35/48, 68/48, and $27 / 53$ etc. 


\section{The Dissolution of the Social Federal Republic of Yugoslavia: The Dayton Peace Agreement}

The dissolution of post-Tito Yugoslavia in 1992 resulted in the notorious 1992-95 war with its traumatic episodes of 'ethnic cleansing' and other war crimes and crimes against humanity, mainly (but not only) perpetrated by ethnic Serbs, which caused internal migrations, affecting in particular the Muslims. Muslims were indeed the main victims of a clearly ideological war while the rest of the western powers were silently observing the mass killing of Bosnian Muslims and Croat Christians. The war was primarily organised and led by three individuals who subsequently were tried at the International Criminal Tribunal for the former Yugoslavia at The Hague: Slobodan Milošević (d. 2006), Radovan Karadžić (b. 1945) and Ratko Mladić (b. 1943). According to one Bosnian historian and thinker, Mustafa Spahić, the genocide that was committed by the Serbs on the Muslims of Bosnia is not the first one, but rather the eleventh in a line of similar events.

During that period, the remains of $a w q \bar{a} f$ which had not yet been devastated and confiscated during the communist regime were almost extinguished by the aggression on Bosnia and Herzegovina. In fact, more than 600 mosques were completely destroyed and almost the same number seriously damaged. ${ }^{29}$ Most of the mosques were destroyed using highly concentrated explosive devises so that the traces of the mosques (and by extension, Islam) would be permanently wiped out from the surface of the earth. Moreover, to complete their work of destruction, the Serbian and Croatian aggressors built parking lots, public parks, markets, buildings, and even rubbish damping sites over the remains of these once sacred places. Furthermore, out of 8,000 Muslim graveyards in Bosnia and Herzegovina at that time, 2,000 were completely devastated and 1,800 were partially damaged. ${ }^{30}$

During the period of aggression, the Presidency of Bosnia and Herzegovina, due to the emergency proclaimed in the country, assumed the functions of the parliament in legislating certain important laws, since parliamentary sessions were prevented from being held by the aggressors' constant attacks on the besieged capital city, Sarajevo. However, it is important to mention here that all the laws and regulations passed by the Presidency at that time were subsequently sent to parliament for ratification once the attacks had decreased. Thus the fundamental principles of democracy were not neglected - even though the country was constantly threatened. ${ }^{31}$ During that time, two very important laws were legislated that were supposed to prevent waqf property as well as the property of other previously nationalised religious institutions from being sold or completely alienated. These laws are:

- Laws on the Prohibition of the Sale of Common Property on which the Right Was Established Through Lease; $;^{32}$ and

- Laws on the Special Protection of Sacred Objects and Places. ${ }^{33}$ 
What amounts to sacred objects and places is explained in section 1 of the Laws on the Special Protection of Sacred Objects and Places which explicitly refers to mosques, churches, chapels, madrasahs, and other theological schools, graveyards, statues, and places that are regarded as sacred. Therefore, waqf property could well be considered as included within this framework because it is the property of Muslims and has special sacred value to them. However, the struggle to get back the huge amount of waqf property which had been confiscated by the communist regime is still on. These laws were practically quite weak in their enforcement process and there was also a lack of political will to return the waqf property to the Islamic Community.

\section{Waqf at Present: Post-Dayton Bosnia and Herzegovina}

It is important to note that the waqf sector in Muslim and secular states is not governed and regulated in the same way. In most of the Muslim countries the institution of waqf is secured and is financed from the state budget. In addition, there is often a special ministry entrusted with the duty of maintaining waqf property. On the other hand, in most of the secular countries or in majority-Muslim states with a secular government and political setup, waqf is regulated and taken care of by the 'Ministry of Religious Affairs' through which the funding is obtained for its maintenance. Furthermore, in most western countries with considerable Muslim minorities, the term waqf is not even mentioned in their legal codes, but some of them use instead different terminologies in order to indicate and regulate the waqf sector. $^{34}$

In Bosnia and Herzegovina, there is no 'Ministry of Waqf'. In fact, there is not even any specific law which mentions the name waqf. The word which indicates waqf is the word 'foundation'. In English the word 'foundation' can be defined as "an organisation that is established to provide money for a particular purpose, for example for scientific research or charity." 35 Therefore, the protection of waqf in the legal documentations of Bosnia and Herzegovina is done through the word 'foundation'. The legal status of foundations in Bosnia and Herzegovina should be observed in the light of the provisions of the Constitution of Bosnia and Herzegovina by which the central government and both its entities have the constitutional obligation to secure the highest level adherence to internationally recognised standards of human rights and fundamental freedoms. ${ }^{36}$ Since the 'foundations' enjoy constitutional recognition, parliament, as a legislative body, was pressured to pass laws to govern and protect them. As a result, in 2001 the Parliament of the Federation of Bosnia and Herzegovina passed a statute called the Law on Associations and Foundations. ${ }^{37}$ This piece of legislation was of great importance to all non-governmental organisations in Bosnia and Herzegovina, including 'foundations'. Thus, this law has legislated indirectly on the protection and legal recognition of waqf, since waqf has been regarded as a 'foundation'. 
One of the main benefits of this legislation is that it legally guarantees the same level of rights to all the people of Bosnia and Herzegovina. Under the same conditions they can realise and protect their human and internationally recognised right to freely associate with others. It is a law applicable to all associations and 'foundations'. However, this law does not apply to three distinguished domains, namely: political parties, religious communities, and union organisations. In fact, there are special laws legislated for each of these domains. For instance, religious communities are governed by the Law on the Freedom of Faith and the Legal Status of Churches and Religious Communities in Bosnia and Herzegovina. As mentioned earlier, when it comes to waqf, there is no specific law legislated to govern its affairs. The last law governing waqf in Bosnia and Herzegovina was legislated and ratified in 1909 and was in force until 1930. Subsequently, the Constitution of the Islamic Community of Bosnia and Herzegovina which was adopted on 13 July 1959 stressed by virtue of Article 25 Paragraph 9 that waqf falls under the jurisdiction of the Presidency of Islamic Community that is supposed to act on the advice of the concerned local community (jama 'at) in issuing the waqfname or endowment certificate in the Bosnian language.

At present, waqf is mentioned and explained in the Constitution of the Islamic Community of 1998. There are a few articles explicitly explaining the matters relating to waqf. Article 28, for instance, says that "the property of the Islamic Community is comprised of waqf, as well as other things like monetary founds." Article 31 states that "every person, individual, or company (legal personality) can in accordance with sharī 'ah laws leave his property as waqf." The Presidency of the Islamic Community, based on constitutional jurisdiction dealing with the waqf affairs, has come out on 22 May 1999 with the Statute of the Waqf Directorate which observes that other organs that are entrusted with jurisdictional powers to deal with waqf affairs are the local Islamic community, special judicial waqf bodies, and mutawallis. ${ }^{38}$ By virtue of Article 32 of the Constitution of the Islamic Community in Bosnia and Herzegovina, the Waqf Directorate manages the property of endowments. Therefore, the management of waqf in Bosnia and Herzegovina should be entrusted to the Waqf Directorate which would be assisted and consulted by three previously mentioned organs. ${ }^{39}$ Furthermore, according to information provided by the former Director of the Waqf Directorate of Bosnia and Herzegovina, Nezim Halilović Muderris, by 24 October 2007 the waqf sector in Bosnia and Herzegovina consisted of 1,144 mosques, 570 masjids, 1,030 shopping lots, 3,027 graveyards, 1,570 houses and apartments, 886 buildings, and 4,829 parcels of land. ${ }^{40}$

\section{The Restitution of Waqf in Bosnia and Herzegovina}

The word 'restitution' comes from the Latin maxim restitutio in integrum which means 'to restore something to its previous position', ${ }^{41}$ thus amounting to the restoration of 
something to its rightful owner. ${ }^{42}$ According to legal dictionaries, the definition of 'restitution' is as follows: "The restoring of anything unjustly taken from another. It signifies also the putting him in possession of lands or tenements, who had been unlawfully disseized of them. ${ }^{43}$ After the Dayton Peace Agreement, ${ }^{44}$ the question of the restitution of waqf property had been raised before the legislative organs of Bosnia and Herzegovina many times. An initial step was taken in December 1996 by the team of experts on matters pertaining to privatisation in the Federation of Bosnia and Herzegovina whereby they drafted the Bill on Restitution. The basis of this bill was the just referred to principle of restitutio in integrum of waqf property which was in existence at that time. If the return of waqf property is not possible, then monetary compensation of equal value was to be paid.

However, the main issue in that bill was in relation to its retrospective effect. In other words, the question posed was whether the bill should be applicable from 1945 or 1918 onwards? ${ }^{45}$ In trying to solve the above issue, in April and May 1997 the team of experts of the Federation together with the Deputy Prime Minister of the Federation of Bosnia and Herzegovina suggested Draft Laws on Restitution according to which restitution should take effect from 1919 until 1992. ${ }^{46}$ After 1997, there were a lot of discussions and many different drafts and bills were proposed until the year of 1999. The last Draft Laws on Restitution was prepared in December 2006.

Unfortunately, these are only Bills and Drafts which were not passed as law. The main reason for not accepting these drafts and bills as law is the existence of two very controversial sections. The first section, known as Section 18, discusses the 'right of possession' and the 'right of ownership' of premises. ${ }^{47}$ The interpretation given by the Resource Ministry for the resources was in favour of the 'right of possession'. Furthermore, it was explained that those who were living in the premises owned by waqf authorities should have the right to stay there since they have the 'right of possession' and since they have stayed there for a long period of time. However, it has to be stated explicitly here that this explanation does not reflect a proper legal understanding. The ownership over those premises is a paramount consideration. It has been explained in many legal systems that adverse possession should not take priority over legal ownership - which belongs to the waqf. Another controversial issue is in relation to Article 24 in which once again the Resource Ministry was advocating the right of those lessees who had leased the working premises and flats which are owned by waqf to buy them accordingly if they wished to before being placed under the legal duty to return them. In other words, the flood gate is open for all lessees to buy the premises for very affordable prices. This proposal is against the legal rules and principles of any democratically-based country. The general rule is clear according to which a lease is for a certain period of time only and the owner of the leased property has the indispensible title over premises and land. ${ }^{48}$ 
One of the important reasons for the law on restitution not being passed and for the lack of efficiency in the execution of restitution is the existence of two advocating groups of people in the restitution disputes. The first group is represented by the Coordination Council for the Return and Compensation of Unlawfully Confiscated and Devastated Property of Religious Communities in Bosnia and Herzegovina. ${ }^{49}$ The legal authority which this group is putting forward is Article 17 of the Declaration of Human Rights (1789) which says that "ownership is sacred and absolute right." Thus, this group demands the return of unlawfully confiscated property. The Coordination Council has submitted to the Environmental Affairs Ministry the statistics on the premises and the apartments that have been unlawfully taken from the religious communities by way of nationalisation. For example, the number of nationalised apartments is as follows: Sarajevo 3,299, Federation 3,531, Republic of Srpska 445. In total, the number of nationalised apartments in Bosnia and Herzegovina amounts to 4,000 which are supposed to be returned to the religious institutions. ${ }^{50}$

On the other hand, there is a second group of people that are represented by an association of citizens advocating the protection of those who are currently in the possession of the apartments or premises which had been nationalised. The name of this association is 'Home'. The main claim put forward by this association is that those who are in the possession of apartments that are legally-owned by religious institutions should be given the right to buy those apartments from the legal owners. ${ }^{51}$ This association has succeeded in persuading certain political circles to amend the law and in allowing them to buy those apartments. Thus, on 21 June 2006, the Federal Parliament of Bosnia and Herzegovina passed the amendments to the Law on Sale of Property (apartments) by 28 votes, 12 against with one abstention. ${ }^{52}$ These amendments grant to those who are in the possession of the confiscated apartments the right to choose (if they wish) to buy those apartments. A few months later, the restitution was tackled by the Commission for Restitution appointed by the cabinet of ministers of Bosnia and Herzegovina which on 27 December 2006 prepared the Draft Law on Denationalisation. However, even this draft has yet to be passed as law since some of its provisions are disputed by some members of parliament.

All in all, currently there are a lot of discussions going on in the political arena, but the laws which are supposed to provide the real restitution of waqf property are yet to be passed. It has been submitted that the restitution of waqf property is the fundamental right guaranteed by many international legal documents such as: ${ }^{53}$

- the United Nations Declarations on Human Rights;

- the European Convention on Protection of Human Rights and Freedom;

- the United Nations Declaration on Basic Principles of Justice for the Victims of War and Misuse of Power (Report A/49/881/ on 29 November 1985);

- the European Social Declaration; 
- the Documents of OESS-a on Human Dimensions (Copenhagen and Moscow);

- the international obligations according to Resolutions 1089 (1996) and 1096 (1996);

- the Resolutions of the European Union B4-1493/95;

- $\quad$ and the Resolution No. 562 of the United States Congress of 1 October 1998.

The battle to establish proper laws for the restitution of waqf property is currently continuing and according to Mr. Mustafa Vatrenjak - himself a mutawalli of one of the most significant waqf properties in Bosnia and Herzegovina - the restitution of waqf property is a basic legal right which should be implemented accordingly. ${ }^{54}$ Moreover, several economic studies have indicated that in order for the state to implement the full restitution of the property unlawfully confiscated from religious communities, it will need BAM 86 billion (c. US\$ 62 billion) - and that process could last for about 30 years. ${ }^{55}$

\section{Conclusion and Recommendations}

This article has aimed at addressing the legal and administrative analysis of waqf in Bosnia and Herzegovina. It can be concluded that

- the attitude of the legislative and political organs of Bosnia and Herzegovina - from the time of the Habsburg period until today - was hostile and destructive towards the institution of waqf. This is evident from the huge amounts of waqf property that have been unlawfully confiscated, especially by way of nationalisation. The proposed draft laws and bills on restitution of unlawfully confiscated property are insufficiently worded in order to be passed as a binding piece of legislation. Unfortunately, the attitude of a large number of communities in Bosnia and Herzegovina contributes to the current delay of restitution being implemented.

- Moreover, the current laws in Bosnia and Herzegovina are not satisfactorily adequate for the proper functioning of waqf.

- There is also an urgent need for an incorporation of fresh elements in the legal system of Bosnia and Herzegovina that would positively change the attitude of the Muslim community towards the welfare of waqf. As it has been indicated in this article, restitution is the natural and legal consequence of the manifold injustices committed against the perpetual usufruct of the community toward the welfare of the waqf property. The illegality of unlawful confiscation through nationalisation is based on several international legal documents which advocate the protection of basic human rights and freedoms. 
- It is hoped that full restitution of waqf property that has been unlawfully taken away through the process of nationalisation in Bosnia and Herzegovina will be achieved in the near future.

\section{Notes}

1. M Hidayatullah and Arshad Hidayatullah, Mulla's Principles of Mahomedan Law (Bombay: N.M. Tripathi Private Ltd, 1996, 19th ed.), 143.

2. Ibid. The concept of waqf exists, of course, also in Shi' ite Islam: for the practice in Iran during the Safavid period, see Christoph Marcinkowski, "Custodians of Sacred Ground: The Mutavallis of Safavid Iran's Major Shi'a Shrines in the Administrative Handbook Dastur al-Muluk," Journal of Shi'a Islamic Studies 1, no. 2 (April 2008), 96-116.

3. Vidyavaruthi v. Balusami 48 I.A. 302; ('22) A.P.C. 123.

4. Hasanuddin Ahmed and Ahmedullah Khan, "Strategies to Develop Waqf Administration in India," Islamic Development Bank, Islamic Research and Training Institute, Research Paper No. 50 (1998), 28.

5. The website of the Department of Waqf in Bosnia and Herzegovina is available at http://www. rijaset.ba (accessed on 20 July 2011). For further details about the organisational structure and the historical chronology of the development of waqf in Bosnia and Herzegovina see also http://www. rijaset.ba/index.php?option $=$ com_content\&view $=$ article\&id $=16 \&$ Itemid $=201$ (accessed on 20 July 2011).

6. Henry Cattan, "The Law of Waqf," in Majid Khadduri and Herbert H. Liebesney (eds.), Law in the Middle East: Origin and Development of Islamic Law (Washington DC: Middle East Institute, 1995), 1:205.

7. The Bogomils were a Gnostic religio-political sect founded in the First Bulgarian Empire by the priest Bogomil during the reign of Tsar Peter I in the tenth century. It most probably arose in what is today the region of Macedonia as a response to the social stratification that occurred as a result of the introduction of feudalism and as a form of political movement and opposition to the Bulgarian state and the church. The Bogomils called for a return to early Christianity, rejecting the ecclesiastical, and their primary political tendencies were resistance to the state and church authorities. This helped the movement spread quickly in the Balkans, gradually expanding throughout the Byzantine Empire and later reaching the Kievan Rus, Bosnia and Herzegovina, Dalmatia, Italy, France, and England. The Bogomils were dualists in that they believed the world was created not by the Abrahamic God, but by an evil demiurge - the Devil. They did not use the cross nor build churches, preferring to perform rituals outdoors; see Dimitri Obolensky, The Bogomils: A Study in Balkan Neo-Manichaeism (Cambridge: Cambridge University Press, 2004).

8. Safet Abid, "Europe's Endangered Species: Yugoslavia's Forgotten Muslims: A Survey of the Indigenous Muslims of Bosnia and Herzegovina Past History- Current Situation- Future Prospects," available online at www.members.tripod.com/worldupdates/islamintheworld/id23.htm (accessed on 20 July 2011).

9. Ibid.

10. Ibid.

11. See the website of Department of Waqf in Bosnia and Herzegovina, available online at http://www. rijaset.ba (accessed on 20 July 2011).

12. For the detailed discussion see Nusret Sehic, Autonomni pokret muslimana za vrijeme austrougarske uprave u Bosni i Hercegovini [The Muslim Autonomous Movement During Austro-Hungarian Rule in Bosnia and Herzegovina], (Sarajevo: Svjetlost, 1980). 
13. The original Bosnian names of these two bodies entrusted with the administration of waqf during the Habsburg period are Zemaljsko Vakufska Komisija (for PWQ) and Zemaljsko Vakufsko Ravnateljstvo (for PWB). The above-mentioned English abbreviations for these bodies are by this writer for the sake of easier reference.

14. Fikret Karcić, The Bosniaks and the Challenges of Modernity, Late Ottoman and Hapsburg Times (Sarajevo: El-Kalem, 1999), 129.

15. Fredo Hauptman (ed.), Borba muslimana Bosne i Hercegovine za vjersku i vakufsku autonomiju [The Struggle of the Muslims of Bosnia and Herzegovina for Religious, Waqf, and Educational Autonomy] (Sarajevo: Arhiv SR BiH, 1967), 26; 49-56; 78-81.

16. Ali Fehmi Dzabić was the muftī of the town of Mostar. He was also known under the name of 'Ali b. Shākir Fahmī Jābirzāde al-Mustarī and had an excellent knowledge of Arabic, literature, and geology. He wrote a number of works such as Husn al-șihābah fi sharh al-șahābah, Tillbat al-țâlib fì sharh Lämiyyah Abī Tălib etc.

17. Karcić, The Bosniaks, 131. For the purpose of practicality, see the memorandum submitted to Béni Kállay de Nagy-Kálló (1839-1903), the Austro-Hungarian ministry of finance and administrator of Bosnia and Herzegovina, on 12 December 1900, published as "Spisi islamskog naroda Bosne i Hercegovine" [Documents of the Muslim Nation of Bosnia and Herzegovina)" (Novi Sad, 1903), $87-138$

18. Fikret Karcić, Medunarodnopravno regulisanje vakufskih pitanja u jugoslovenskim zemljama [Solving the Issues of Waqf by International Law in the States of Yugoslavia], (Sarajevo, 1983), 148.

19. Abid, "Europe's Endangered Species."

20. The Islamic Community of Bosnia and Herzegovina is independent in regulating its activities and managing its assets and bases this autonomy on the legality of religious institutions pertaining to Bosnian Muslims since the period of Ottoman rule in Bosnia. With the establishment of the AustroHungarian administration in Bosnia and Herzegovina, official attempts were made to disconnect the Muslims of Bosnia and Herzegovina from Istanbul, their 'spiritual headquarters' and orientation. Initially, the supreme religious authority of the Ottoman Empire, the şeyhülislam (shaykh al-islām) in Istanbul, refused to give his consent for the establishment of an independent Islamic community in Bosnia and Herzegovina. However, in 1882 he appointed Hilmi ef. Omerović of Sarajevo as the Bosnian muftī and authorised him to appoint junior clerics and judges. As a result, on 17 October 1882, by decree of the Emperor Francis Joseph, the Austro-Hungarian government appointed Hilmi ef. Omerović as Bosnian mufti and proclaimed him as the first $r a-\bar{l} s$ al- 'ulama ' of Bosnia and Herzegovina. 1882 is therefore also the year of the forming of the independent Islamic Community of Bosnia and Herzegovina. The Islamic Community of Bosnia and Herzegovina constitutes the community of Muslims living in Bosnia and Herzegovina, of Bosniaks living outside their homeland and other Muslims who accept this community as their own. The mesihat of the Islamic Community of Sandžak (in Serbia), the mesihat of the Islamic Community of Croatia and the mesihat of the Islamic Community of Slovenia are all constituents of the Islamic Community of Bosnia and Herzegovina. The objective of the Islamic Community presents an endeavour to have all its members living in accordance with Islamic norms. This objective is realised and achieved through the Islamic principles of the 'promotion of good and diverting from evil'.

21. For further information see Mustafa Imamovic, "Pregled razvitka Islamske Zajednice u Bosni I Hercegovini" [A Survey of the development of the Islamic Community in Bosnia and Herzegovina], Glasnik Rijaseta Islamske zajednice u Republici Bosni i Hercegovini 61 (1994), 1-3, 53-63.

22. Senad Ceman, "Komparativna studija o polozaju vakufa i fondacija u serijatkom pravu i pozitivnim zakonima propisanim u Bosni i Hrcegovini” [Comparative Study of Waqfs and Foundations under Sharī ah Law and Positive Law Legislated in Bosnia and Herzegovina], MA thesis, University of 
Sarajevo, 2007, 104; hereafter cited as Ceman, "Comparative Study."

23. There is A Memorandum to the Presidency of Bosnia and Herzegovina (Sarajevo, 1997) submitted by the Islamic Community of Bosnia and Herzegovina for the compensation and restitution of all the properties of the Islamic Community including awqa $f$ that have been devastated and nationalised (see p. 94).

24. This statute was published in No.2 of the Official Gazette of Federal Republic of Bosnia and Herzegovina on 9 January 1945.

25. Ceman, "Comparative Study," 107.

26. For a particular example of nationalisation of the waqf of Gazi Hüsrev Bey see http://www.vakufgazi.ba (accessed on 20 July 2011).

27. Ceman, "Comparative Study," 107.

28. Ceman, "Comparative Study," 107 and 108.

29. Muharem Omerdić, Prilozi izucavanja genocida nad bosnjacima (1992-1995) [Samples for the Study of the Genocide on Bosniaks] (Sarajevo: El-Kalem, 1999), 476, and sample no. 4, at p. 147; Ceman, "Comparative Study," 112.

30. Omerdić, Prilozi, 24 and 25.

31. See Mustafa Begić (ed.), Zemljovlasnici Bosne: vlasnicke pravne norme od disolucije (31.12.1991) ex-Jugoslavije do potpisivanja Dejtonskog sporazuma (14.12.1995) [Landlords of Bosnia: Legal Norms of Ownership from the Dissolution (31 December 1991) of ex-Yugoslavia until the Signing of the Dayton Peace Agreement (14 December 1995) (Sarajevo, 2000), 3:9.

32. Official Gazette of the Socialist Republic of Bosnia and Herzegovina, No. 4 (17 February 1992), 100.

33. Official Gazette of the Socialist Republic of Bosnia and Herzegovina, No. 13 (June 1993), 324-25.

34. Zarko Paunovic, "Nevaldine organizacije" [Non-governmental Organisations], JP Official Gazette (Beograd, 2006), 26; Ceman, "Comparative Study," 14. For the sake of illustration, the term waqf is indicated by different terminologies in most of western countries where rather different terminologies are used: for instance, in the United States the term 'non-profit sector' is used, in England 'voluntary sector', in France 'secteur économique'. In many developing countries, it is covered by the term 'non-governmental organisations'. Besides, some other countries use terminologies such as 'third sector', 'charitable sector', 'civil society organisations', 'independent sector', 'associational sector', and 'tax-exempted sector'.

35. Oxford Advanced Learner's Dictionary (Oxford: Oxford University Press, 2005, 7th ed.).

36. Ceman, "Comparative Study," 136.

37. The Law on Associations and Foundations was passed by the Parliament of the Federation of Bosnia and Herzegovina in both Houses in 2002 (No. 01-3-02-3-46/02). It was also passed by the Parliament of Bosnia and Herzegovina on 5 October 2001.

38. Muhamed Salikić, Ustavi islamske zajednice [Constitutions of the Islamic Community] (Sarajevo: El-Kalem, 2001), 352.

39. Esad Hrvacić, "Restitucija i njeno pravno utemeljenje" [Restitution and Its Legal Origins], Hikmet [Tuzla, Bosnia and Herzegovina], no. 9-12 (December 2000), 265.

40. Ceman, "Comparative Study," 159.

41. Datinder S. Sodhi and R.S. Vasan, Latin Words and Phrases for Lawyers (Don Mills (Ontario, Canada) and New York: Law and Business Publications (Canada) Inc, 1980), 216.

42. See the definition in "Merriam-Webster Online Dictionary," available online at http://www. merriam-webster.com/dictionary/restitution (accessed on 20 July 2011).

43. Sinha and Dheeraj, Legal Dictionary (Kuala Lumpur: International Law Book Services, 1996), 315.

44. The Dayton Peace Agreement, signed on 14 December1995, officially ended the aggression on Bosnia and Herzegovina. 
45. The Islamic Community of Bosnia and Herzegovina did not accept any of the above two dates because of the huge amount of waqf property confiscated since 1886.

46. Ceman, "Comparative Study," 114.

47. See the speech given before the Parliament of Bosnia and Herzegovina on 11 July 2000. The speech was prepared by advocate and solicitor Hrvacic Esad and is available in Ceman, "Comparative Study," 153.

48. Ibid.

49. Ceman, "Comparative Study," 117.

50. Ibid. It is interesting to note that the highest number of apartments that have been unlawfully confiscated by way of nationalisation are the apartments and premises which belonged to the Islamic Community of Bosnia and Herzegovina whereby until 1961, 803 objects were nationalised. The Orthodox Church had lost in this period 149 objects while the Roman Catholic Church had lost 36 objects. There are reports that the Jewish community too had lost four buildings by way of nationalisation. This overall statistic can be found in the report prepared by the Commission for Nationalisation of the Socialist Republic of Bosnia and Herzegovina and also by the Commission for Religious Affairs.

51. Ceman, "Comparative Study," 118.

52. See the newspaper article entitled "The Law on Sale of Property (Apartments) Has Been Passed," Dnevni Avaz (Sarajevo), 23 June 2006 (in Bosnian).

53. Information retrieved on 21 August 2009 from http://www.vakuf-gazi.ba/.

54. Ibid.

55. Ceman, "Comparative Study," 140. 